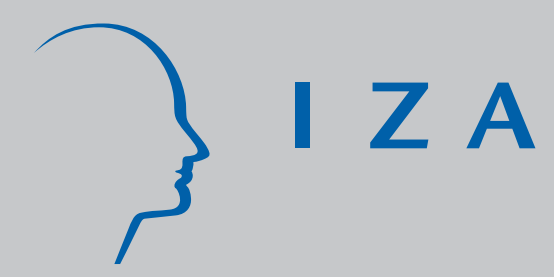

IZA DP No. 1929

Satisfaction with Democracy and the Environment in Western Europe:

A Panel Analysis

Alexander F. Wagner

Friedrich Schneider

J anuary 2006 


\title{
Satisfaction with Democracy and the Environment in Western Europe: A Panel Analysis
}

\author{
Alexander F. Wagner \\ Swiss Banking Institute, University of Zurich \\ and University of Linz \\ Friedrich Schneider \\ University of Linz \\ and IZA Bonn
}

Discussion Paper No. 1929
January 2006

IZA

P.O. Box 7240

53072 Bonn

Germany

Phone: +49-228-3894-0

Fax: +49-228-3894-180

Email: iza@iza.org

\begin{abstract}
Any opinions expressed here are those of the author(s) and not those of the institute. Research disseminated by IZA may include views on policy, but the institute itself takes no institutional policy positions.

The Institute for the Study of Labor (IZA) in Bonn is a local and virtual international research center and a place of communication between science, politics and business. IZA is an independent nonprofit company supported by Deutsche Post World Net. The center is associated with the University of Bonn and offers a stimulating research environment through its research networks, research support, and visitors and doctoral programs. IZA engages in (i) original and internationally competitive research in all fields of labor economics, (ii) development of policy concepts, and (iii) dissemination of research results and concepts to the interested public.
\end{abstract}

IZA Discussion Papers often represent preliminary work and are circulated to encourage discussion. Citation of such a paper should account for its provisional character. A revised version may be available directly from the author. 
IZA Discussion Paper No. 1929

January 2006

\section{ABSTRACT \\ Satisfaction with Democracy and the Environment in Western Europe: A Panel Analysis*}

We construct a panel of satisfaction with democracy (SWD) and economic, institutional, and environmental variables for 1990-2001 for fifteen European countries. In this sample, controlling for a number of factors, we find that average SWD is higher where (1) there exists an energy / CO2 tax, where (2) government expenditures on the environment are higher, where (3) certain environmental regulations like packaging rules are in place, and (4) where the government puts in place environmental offices or other official bodies charged with addressing environmental concerns. We also find that, on the environmental quality side, (5) more cars on the roads, (6) less unleaded fuel, and (7) higher pesticide use intensity all decrease SWD.

JEL Classification: K32, P16, Q21, Q28

Keywords: satisfaction with democracy, environment

Corresponding author:

Friedrich Schneider

Energieinstitut and Department of Economics

University of Linz

Altenberger Strasse 69

A-4040 Linz-Auhof

Austria

Email: friedrich.schneider@jku.at

\footnotetext{
* We would like to thank Silke Mader and Jürgen Wegmayr for research assistance and the Jubiläumsfonds of the Austrian National Bank for financial support (project no. 10939). We thank Pippa Norris and Gernot Wagner for helpful comments.
} 


\section{Introduction}

In this paper, we analyze how environmental factors affect citizens' satisfaction with the "constitution in operation," as measured by survey data on satisfaction with democracy (SWD). To do so, we employ (for the first time, to our knowledge) a panel of SWD in Western European countries in the time span 1990-2001. We find that environmental quality and policy matter in statistically and economically important ways. In general, more environmental regulation and higher environmental quality lead to higher satisfaction with democracy, but with notable exceptions.

Research on satisfaction with democracy (SWD) is important because scholars interested in the political economy of democracy often still tend to compare countries on the basis of more or less objective indicators of the degree of democracy. But quite obviously even countries that achieve exactly the same democracy ranking in, say, the Freedom House index, will not offer the same degree of satisfaction with the way democracy works to their citizens. Much as we want to know what drives subjective perceptions of personal happiness in life (Frey and Stutzer 2002), scholars and policymakers should be interested in what drives subjective perceptions of SWD. There exists a growing literature on the subject, and some papers study the relationship between personal happiness and environmental factors, but we have not found any existing evidence on the relationship between SWD and the environment.

This is surprising, given that environmental factors are likely to be related to SWD and not merely to individual well-being. After all, environmental problems are inherently collective action problems. Thus, the extent to which a country is able to address environmental issues is also a reflection on how well it is able to resolve such problems. 
In fact, the study of the relationship between SWD and the environment is one specific application of a broader interest, namely, whether collective action problems and their solutions feature in citizens' perceptions of what is important for a well-functioning democracy. From an environmental policy perspective, it is also useful to have an aggregate-level complement to the many studies that value environmental amenities using site-specific methods.

Motivated by these observations, in this paper we in quantify the impact of environmental quality and environmental policy on satisfaction with democracy as it is measured by Euro-Barometers, cross-national surveys in Western Europe. We hypothesize that better environmental quality and the existence of policy directed at improving environmental quality increase satisfaction with democracy. All in all, we find considerable support for this hypothesis, but with some interesting qualifications.

In particular, we find that controlling for various economic and political variables that have been found to be significantly related to SWD in other studies, a government's commitment to improving environmental quality, as measured in a number of actually implemented policies, generally leads to higher SWD. For example, the existence of a specifically designed energy or CO2 tax, the existence of sustainability councils, environmental offices, or ministries of the environment, the definition of environmental protection as a constitutional goal, and higher government expenditures for the environment are all positively and robustly related to SWD. These effects are also quantitatively important: An increase in environmental spending as a fraction of GDP by one percentage point increases SWD by three quarters of a standard deviation; introducing an environmental office leads to an increase in SWD of a third of a standard 
deviation. Somewhat surprisingly, however, but equally robustly, the implementation of a nature conservancy act on average leads to a reduction of SWD by about half a standard deviation. This is the only policy measure for which this result occurs. Thus, while this particular finding remains a puzzle at this point, and future work will have to clarify why it arises, the overall picture that emerges shows that environmental policy is generally appreciated by citizens.

Besides from policy, we also consider environmental quality directly. Results are mixed for variables that seem likely to measure this concept. While some of the environmental quality variables we consider are robustly and strongly related to SWD, others are not. In particular, average SWD is strongly negatively affected by the use of pesticides, more cars on the road, and more unleaded fuel. Beyond these three variables, few relationships survive a rigorous econometric test.

In a sense, this last result is not too surprising. In fact, it has probably to do with what is, we freely admit, the biggest drawback of this study. In particular, our findings provide insight only into the aggregate relationship between average SWD and the environment. Indeed, the econometric framework assumes homogenous preferences across the countries we are analyzing. This is why we restrict our attention in this paper to the Western European countries. It is also important to note that the use of individual-level data for satisfaction alone would not help to solve the problem. We would also need individual-level data for environmental quality, and this sort of data does not exist, at least not in a dataset that has also measured individuals' satisfaction. ${ }^{1}$ The problem is

1 Many researchers have extended the basic Eurobarometer data by including data on political and institutional variables. For example, in a seminal paper, Anderson and Guillory (1997) find support for the 
well-known from other areas. For example, in the valuation literature, there are recent papers which also focus on nation-wide comparisons of fishing values (Bennear, Stavins, and Wagner 2006), hunting values (Loomis, Pierce, and Manfredo 2000), etc. even though also in these cases preferences would not appear completely homogenous across states. $^{2}$ Thus, much like these studies are complements to individual, site- or countryspecific studies of values of environmental amenities, this paper also is a complement to site- or country-specific studies of the relationship between the environment and wellbeing.

A massive literature exists on valuation of environmental amenities, but virtually nothing is available in terms of the relationship between broad measures of satisfaction and environmental quality. ${ }^{3}$ Three recent papers have focused their work on the interaction between happiness (which is correlated with satisfaction, but measures

hypothesis that consensual systems (in the sense of Ljiphart) allow "losers", i.e., individuals who voted for a party in the last election that is now not part of the government, to retain a higher SWD than majoritarian systems. See Wagner and Schneider (2005a) for a similar approach. Unfortunately, all these studies suffer from an important econometric problem: Fixed effects cannot be accounted for in a context where the institutional or environmental variable does not vary differently than the panel groups. In other words, if the environmental policy or quality variable is only observed on the country level, it is not clear whether the effect that happens to be ascribed to the institutional variable included in the regression is in fact related to the variable, or whether that variable picks up a different country-fixed effect.

${ }^{2}$ Loosely speaking, what is required for our method to be equally appropriate as that of the cited papers is that preferences regarding environmental policy quality do not vary more across European countries than do the preferences regarding recreational fishing or hunting of American citizens across US states.

${ }^{3}$ By contrast, a number of recent papers have focused on SWD and its political economy determinants. Wagner and Schneider (2005a) review that literature. 
individual life satisfaction, rather than satisfaction with the way democracy works) and environmental issues. ${ }^{4}$ Welsch (2005) has shown that air pollution plays a significant role for subjective well-being ("happiness") in a panel analysis for ten European countries. ${ }^{5}$ In particular, Welsch's results indicate that nitrogen, particles and lead all are negatively related to happiness in economically important ways. Rehdanz and Maddison (2005) examine the relationship between climate and happiness in an empirical analysis using data of 67 countries. Controlling for a number of variables, ${ }^{6}$ they show that happiness increases with higher mean temperature in the coldest month and decreases with higher mean temperatures in the hottest month as well as that it decreases with a bigger number of months with very little precipitation. Finally, Israel and Levinson (2003) find that with increasing per capita water pollution happiness decreases.

All existing studies have focused on happiness; none of the existing papers has considered satisfaction with democracy as the dependent variable. Moreover, environmental policy has not been considered as an explanatory variable. Both deficiencies of the literature so far thus concern the public side of environmental issues, as opposed to the more individual-level issues that were the focus of previous papers. This paper fills this gap.

\footnotetext{
${ }^{4}$ For a survey in progress, see Wegmayr (2005).

${ }^{5}$ In earlier work, Welsch (2002) showed similar results in a cross-sectional dataset.

${ }^{6}$ GDP per capita, annual growth rate of GDP, unemployment and inflation rates, as well as the proportion of different religions to measure cultural differences and an index for freedom measured as political rights and civil liberty and life expectancy and the literacy rate.
} 
The rest of the paper is organized as follows. Section 2 discusses the concept of SWD. Section 3 presents hypotheses and describes the data used. Section 4 presents the main quantitative findings, and Section 5 concludes.

\section{Conceptualizing SWD}

Although SWD has been widely used in the political science literature, SWD has also been under considerable criticism as a concept. Despite the problems attached to the concept and measurement of "satisfaction with democracy," we see it as a very useful measure of our (unobserved) variable of interest, namely, satisfaction with "the constitution in operation” (Klingemann and Fuchs 1995). We take the pragmatic view that the SWD item can serve as a summary indicator (Clarke, Dutt et al. 1993). ${ }^{7}$ Although it contains some ambiguity, that ambiguity is acceptable.

Nevertheless, we expect that "satisfaction with democracy" cannot but be extremely hard to predict, since it is driven by individual interpretation on both sides of the "discrepancy": what democracy should look like, and the way it works. To understand a bit better the arguments that have been made, let us consider the literature. Linde and Ekman (2003) provide an excellent survey of the concept of SWD, and we refer the reader to their paper for a discussion. They conclude (p. 401) that the item "“satisfaction with the way democracy works' is not an indicator of system legitimacy per se. Rather, it is one indicator of support for the performance of a democratic regime." Thus, SWD

\footnotetext{
${ }^{7}$ Others are more critical. See, e.g., Canache, Mondak et al. 2001.
} 
does not attempt to capture whether people support the principles of democracy, but rather how they judge it to work in practice in their concrete experience. ${ }^{8}$

Linde and Ekman (2003) also point out that there are benefits that arise from the longitudinal study of satisfaction with democracy. In particular, they argue (p. 405-406) that "even if everybody agrees that the Eurobarometer, the Central and Eastern Eurobarometer and the Candidate Countries Eurobarometer (CCEB) all have serious limitations, at least these surveys - since they have been around for quite some time - do provide us with time series data that may be utilised to make meaningful statements about public support for democracy.” As noted by Lipset (1959), Easton (1965, 1975), and Almond and Verba (1963, 1980), generalized or diffuse support (e.g., support for regime principles) does not emerge overnight. Rather, it must be built on a record of acknowledged regime performance or 'system outputs' or, to put it differently, on a history of specific support. It should be noted that 'system outputs' are not only of an economic nature, say, a matter of economic growth or social reforms. At least on a theoretical level, for the creation of a reserve of generalised system support, the regime's capacity to address public concerns, like the environment, is crucial. As Linde and Ekman point out, “a permanent performance deficit, for example, erodes diffuse support

\footnotetext{
${ }^{8}$ Although it is problematic to assess the level of legitimacy of democracy by using the items we find in the major cross-national public opinion surveys, SWD remains the most commonly used indicator of generalized support for the democratic system. This paper, however, is specifically not about legitimacy or the consolidation of democracy. It is about how democracy works in practice. We should emphasize that we are not claiming that our findings apply directly to the "new" democracies of Eastern Europe, neither statically nor as a dynamic predictor for what is likely to happen with democracy in those countries.
} 
in the long run. Conversely, democratic legitimacy (support for the principles of democracy) derives to a great extent from the long-term performance of the democratic regime. In other words, time series data allow us to assess at least some aspects of the level of democracy's legitimacy, even if we are left with nothing but performance indicators." It is this view, combined with the notion that environmental issues are among the central issues to dominate public discussion and concern in recent years, that underlies the analysis of this paper.

\section{Data and methodology}

We first discuss our dependent variable, then our key explanatory variables, and then our control variables. We sum up this section by presenting the regression equation that we estimate and the signs of the coefficients that we expect.

\subsection{Dependent variable}

We began by collecting all available data on satisfaction with democracy in Western Europe in the period 1990-2001. ${ }^{9}$ This posed considerable logistical problems, as the Eurobarometer unfortunately does not ask the question at the same point in the survey every time. This required sorting through approximately 80 codebooks of Eurobarometers in the period under consideration. Even so, data was not available for all years and all countries. For most countries, data was available for all years except 1995 and 1998, and for countries that joined the European Union in 1995, data was only

\footnotetext{
${ }^{9}$ More data is in principle available for SWD. But data for our explanatory variables is limited as well, so we constrain ourselves to the available sample period in discussing the development of SWD.
} 
available for the second half of the decade. After collecting the individual year data, we calculated average satisfaction with democracy.

Figure 1 shows, by country, how our dependent variable develops over time. Importantly, average satisfaction with democracy fluctuates enormously over time. A key insight we can draw from this picture is that analyses that focus on one year - as all existing articles have done so far - are likely to be incomplete.

Figure 1 also illustrates that, as is known from anecdotes, Denmark and Luxembourg do very well in terms of satisfying their citizens' expectations towards the democracy. The most satisfied country-years were (in this order) Denmark (2001), Norway (1994), Luxembourg (1991), Denmark (1997), and Denmark (1994); among the top 15 countryyears in terms of average SWD, there were only 3 which are not those of Denmark and Luxembourg. The three highest levels of average dissatisfaction in the whole European Union from 1990 to 2001 all occurred in Italy (in 1992, 1993, and 1996, respectively); of the top 15 country-years in terms of average dissatisfaction, 9 are those of Italy.

\subsection{Environmental variables}

Our primary interest in this study is the impact of environmental factors on SWD. We use both environmental quality measures and environmental policy variables to learn about this relationship. This dual approach is attractive because both types of measures have advantages and disadvantages.

Our environmental quality measures are taken from the World Resources Institute website (www.wri.org) as well as from the OECD and from Eurostat. We have employed a very wide array of variables. For space reasons, we do not list all 29 variables here; they include the number of cars, fertilizer and pesticide use intensity, agricultural yields, 
wood fuel production, emissions of the most important pollutants, roads, municipal waste, and many others. The appendix shows the descriptive statistics for all variables.

Our environmental policy measures are collected from Binder (2002) and Busch and Joergens 2002). For a wide array of policy measures (21 different measures), these authors have collected a dataset indicating whether a particular country had implemented a certain measure in a given year. The policy variables are dummy variables. For example, ENERGYCO2TAX is equal to 1 when a country had implemented an energy tax in a given year; otherwise it is 0 . The data covers essentially the full spectrum of environmental regulation: from subsidies for renewable energy to environmental ministries, from environmental labels to the existence of a nature conservancy act. We also calculate a summary measure, ENVIRONMENTAL POLICY, which is the sum of all policy variables. For our sample, it takes on a value between 4 and 21 and encapsulates the degree to which a country has established a comprehensive set of environmental policy measures. Detailed data description is available on request, ${ }^{10}$ but in most cases the variable names are essentially self-explanatory. It is apparent from the descriptive statistics in the appendix that even in the 1990s there was tremendous variation in the implementation of environmental policy across European countries.

Quite simply, we hypothesize that higher environmental quality leads to greater satisfaction with democracy. We also want to test the idea that environmental policy is

\footnotetext{
${ }^{10}$ We obtained the data by reading them from the graphs in Binder (2002). The graphs are fortunately of the quality that they allow the unambiguous identification of all cases.
} 
generally seen as an important aspect of a well-functioning democracy and will therefore also lead to more SWD. Therefore, we posit:

Hypothesis 1: Better environmental quality is associated with higher SWD.

Hypothesis 2: Countries with more environmental policy experience higher SWD.

\subsection{Economic variables}

To control for various determinants of SWD other than environmental factors, we employ a set of economic and political control variables. First, the worse the overall economic performance of a country, the lower average satisfaction with democracy is expected to be. This hypothesis in itself is not suprising, and indeed individual-level regressions show that richer, working individuals are more satisfied than poorer, unemployed individuals (see, for example, Wagner and Schneider 2005a). As proxies for the overall economic performance we use data on UNEMPLOYMENT, and (log) INFLATION. Beyond these two variables, it is questionable which economic variables we should control for. After all, hardly any non-economist would seem to care directly for government debt (except perhaps in extreme cases) or openness. Moreover, these variables are arguably strongly endogenous to institutional quality. Therefore, we restrict ourselves to these basic economic control variables in the main specification, and deal with larger sets of economic controls (including, for example, GROWTH (GDP growth per capita) only in the robustness tests.

Hypothesis 3: Better economic performance (lower unemployment and lower inflation) is associated with higher SWD. 


\subsection{Happiness}

In the main specification, we also control for happiness (life satisfaction) as measured by the Eurobarometer. Like for SWD, we collected this data by hand from the various surveys and then calculated the average for each country and available year. We use happiness as a control variable for two primary reasons: First, this way we do not have to separately include too many control variables that might determine SWD, but whose inclusion in the regression would also the number of the degrees of freedom. Second, insofar as there is multicollinearity between happiness and environmental quality or policy, this would merely negatively affect the precision with which we are able to estimate the effects; the estimator would still be unbiased. In other words, to the extent that we find statistically significant results, our trust in them is even greater in the presence of possible multicollinearity. A third reason is that to our knowledge the correlation between SWD and happiness has not been documented yet, at least not across time. We comment on the endogeneity between happiness and SWD in our robustness section.

Hypothesis 4: More happiness is associated with higher SWD.

\subsection{Estimation strategy}

Summarizing, in the main specification, we estimate a panel regression of the form

$$
\begin{aligned}
\text { SWD }_{i t}= & \alpha+\beta_{1} \text { HAPPINESS }_{i t}+\beta_{2} \text { UNEMPL }_{i t}+\beta_{3} \text { INFLATION }_{i t} \\
& +\gamma E N V I R O N M E N T_{i t}+\varepsilon_{i t}
\end{aligned}
$$


where the indices "it" indicate that we have panel data (countries and years) for all the relevant dependent and explanatory variables. ENVIRONMENT is a place holder for all the environmental variables we are interested in.

Our dependent variable is average satisfaction with democracy. A higher value of SWD indicates greater satisfaction. ${ }^{11}$ To be consistent with our hypotheses, we therefore expect $\beta_{1}>0, \beta_{2}<0, \beta_{3}<0$, for the control variables. As for the environment, we expect their coefficients to reflect that better environmental quality and policy promote SWD. In other words, we expect $\gamma>0$.

\section{Empirical results}

\subsection{Basic correlations}

We begin by considering the basic correlations between our variables of interest. Table 2 shows these. What is striking about the first column is that several, though not all environmental quality and policy indicators are positively related to satisfaction with democracy. As an example, consider pesticide use intensity: The partial correlation with SWD is minus 0.43 , and this negative relationship is also apparent from Figure 2.

The environmental variables among themselves are correlated, but not extremely highly so. This suggests that it is worth considering each variable separately.

\footnotetext{
${ }^{11}$ In the individual survey, a value of 4 means an individual is "very satisfied," whereas a value of 1 means an individual is "not at all satisfied."
} 


\subsection{Main specification with multiple regressors}

While these observations allow us some first insights, we need to make the analysis more statistically rigorous by running regressions with more explanatory variables. The primary results from random effects panel regressions are summarized in tables 3 and 4 .

\subsubsection{Economic variables and happiness}

We can first verify that the effects of the basic control variables go in the expected direction:

1. Countries and years with higher unemployment growth have lower satisfaction with democracy.

2. Countries and years with higher inflation have lower satisfaction with democracy.

3. Greater happiness is associated with greater satisfaction with democracy. ${ }^{12}$

In other words, hypotheses 3 and 4 cannot be rejected. While these findings are certainly intuitive and reflect what was to be expected, it is noteworthy that this appears to be the first systematic multi-year evidence on these relationships that is available.

\subsubsection{Environmental policy variables}

Consider Table 3. This table shows that, controlling for happiness, unemployment, and inflation,

- an energy or $\mathrm{CO}_{2}$ tax (column 2),

- the existence of specific packaging rules (column 3),

\footnotetext{
${ }^{12}$ We comment on simultaneity issues below.
} 
- the introduction of a sustainability council (column 4),

- the existence of an environmental office (column 5),

- defining environmental protection as a constitutional goal (column 6),

- the existence of a ministry of the environment (column 7), ${ }^{13}$

- higher government expenditures on the environment per capita or in percent of GDP (columns 9 and 10)

all lead to higher degrees of SWD. The same is true for a summary measure that sums up all environmental policy variables presented in Binder (2002), as shown in column (12).

Other variables are not typically significant once one controls for either happiness or other variables. In particular, the size of environmental taxes does not appear to have a significant impact on how satisfied people are with the way democracy works, controlling for other economic variables (column 11). Energy efficiency labels, subsidies for renewable energy, and the existence of an environmental information act are also not significant. (These results are not shown, but are available on request.)

What is surprising, finally, is that European citizens appear to strongly dislike nature conservancy acts, as indicated by the negative coefficient in column (8). It is quite hard to tell a meaningful story for why this result arises. At this point, we can only speculate that this effect may have to do with a perceived over-regulation and the fact that it is nature conservancy acts which frequently stand in the way of individualized housebuilding, something that many citizens would appear to value. It is unfortunately

\footnotetext{
${ }^{13}$ This particular finding is ultimately not of great policy significance, as most countries in the sample implemented ministeries early on.
} 
unclear how one would detect this aspect in this dataset. Thus, this finding remains as a puzzle that may induce future researchers to investigate it more closely. But in our view the fact that nine quite different environmental policy measures affect SWD positively stays the primary message to take away from this analysis.

Returning to the variables that positively affect SWD, it is noteworthy that the effects implied by these regression results are also economically significant. To see this, first select an environmental variable of interest. Since we have estimated a linear regression, the coefficients can be interpreted very directly without the need for simulations. Column 10 in conjunction with the descriptive statistics for SWD implies that an increase in environmental spending as a fraction of GDP by one percentage point increases SWD by three quarters of a standard deviation. Similarly, introducing an environmental office leads to an increase in SWD of a third of a standard deviation, as can be derived by comparing the coefficient in column 5 with SWD's variance. Some uncertainty surrounds these results, but the ultimate message from the full picture remains clear: Citizens in Europe feel that an active environmental policy should be part of a wellfunctioning democracy.

\subsubsection{Environmental quality variables}

While citizens appear to strongly care about environmental policy, the results are less clear regarding environmental quality. Table 4 shows that

- more cars (column 2),

- a higher pesticide use intensity (column 3),

- lower paper recycling rates (column 6),

- more leaded fuel (column 12), and 
- fewer agricultural workers (column 1$)^{14}$

significantly decrease SWD. Again, the effects are quantitatively significant: A one standard deviation decrease in pesticide use increases SWD by a third of a standard deviation. A curious, but interesting finding is the fact that people want more cars, but fewer roads (column 14), although this finding is not very highly significant.

Organic pollutant emissions, SOx emissions, and NOx emissions also have a negative effect on SWD, but its statistical significance is very low. This may partly have to do with the fact that these variables are highly negatively correlated with happiness. A second aspect is that more pollution also goes hand in hand with more output (and less unemployment), which in turn positively affects SWD. This multicollinearity would lead to overly wide confidence intervals, although the estimates themselves remain unbiased. But even the partial correlation between emissions and SWD is not very high. There is also a second explanation for this lack of a statistical relationship: Pollutants are likely to be highly concentrated in a view areas of a country. They may very well have an impact on SWD, but this impact is likely to be disguised by the averaging of SWD and the consideration of country-wide variables. By contrast, the environmental policy variables above as well as the few environmental quality variables which are in fact significant (number of cars, type of petrol, pesticides, recycling) would seem to affect a broader range of the population.

\footnotetext{
${ }^{14}$ This is of course not a direct environmental quality measure. The notion is that one of the central functions of farming, at least nowadays, is not the actual production of edible goods, but landscape conversation.
} 


\subsection{Deepening the analysis}

We now show the findings of including additional variables, changing the specification, and generally exploring the robustness of the results in the main specification. The basic conclusion is that the results remain similar as before.

\section{Political variables}

First, we consider political variables. Wagner and Schneider (2005b) study to which extent institutions ("rules of the game”) that promote the quality of resource allocation, political participation, and provision of public goods increase SWD. They find that some measures of institutional quality are strongly and robustly related to SWD. We also consider these measures as control variables in the present study. ${ }^{15}$ In particular, we use the BERI Composite Index as the primary measure for high-quality institutions. ${ }^{16} \mathrm{~A}$ second idea is that macroeconomic outcomes are at least partially determined through the policy-making process, and so it is appropriate to see what underlying variables govern this process. It turns out that division on social issues, i.e., ideological diversity, is one of the most powerful predictors of bad policy. We measure this by constructing an index, LEFTRIGHTSD, which is the standard deviation of LEFTRIGHT, which in turn is the self-reported position on the left-right spectrum.

Hypothesis 5: Better institutional quality increases SWD.

\footnotetext{
${ }^{15}$ Also, a very large literature shows that institutional quality and economic growth are positively related.

${ }^{16}$ Wagner and Schneider (2005b) discuss many additional variables, and in an appendix available on request we show that the results presented in this paper are largely robust to the use of those alternative proxies for institutional quality.
} 
Hypothesis 6: Greater ideological diversity decreases SWD.

Hypothesis 6 is strongly supported by our findings in Tables 5 and 6. By contrast, institutional quality, at least once we control for happiness and other macroeconomic variables does not seem to matter much for SWD.

What is important for our study, however, is the fact that many environmental policy variables remain equally significant, both statistically and economically, as before. Higher government expenditures on the environment (columns 2, 6, and 12), packaging rules (columns 3 and 13), and energy or CO2 taxes (columns 7 and 8) increase SWD. (The tables show several self-explanatory variations of the specification.) But equally strongly, the result regarding the negative effect of a nature conservancy act also survives the robustness test.

Finally, while no new environmental quality variables become significant in these robustness tests, the primary variables that played a role in the main specification remain significant here as well: pesticide use (columns 3, 6, 7, and 10), landscape conservation (columns 1, 4, and 8), and the number of cars (columns 2, 5, 9).

\section{$\underline{\text { Time dummies }}$}

For all variables except for the summary variable "ENVPOLICY," the results remain very similar if we include year dummies into our regressions. Tables 5 and 6 show these results for the main specifications. The fact that ENVPOLICY (last column) becomes insignificant is not particularly surprising, given that this variable is the sum over the years and therefore has a stronger upward trend built in than the individual policy variables, which, once they have been implemented, continue with a value " 1 " in the 
dataset. In Table 5, we also find that, interestingly, ideological diversity is strongly correlated with time - in particular, columns (4-6) and (8-10) illustrate that once one includes time dummies, ideological diversity itself becomes insignificant.

\section{Political orientation}

One might hypothesize that environmental regulation is regarded by some as a special form of state interference in individual matters. In particular, one might think that those who view themselves as more "leftist," would approve more of environmental policy measures. This idea can be tested by including a variable measuring political orientation, LEANINGLEFT, and an interaction terms LEANINGLEFT * ENVPOLICY, where ENVPOLICY stands for a measure of environmental policy. It turns out that the interaction term is never significant. (Incidentally, neither is LEANINGLEFT individually significant. In other words, ideological orientation does not matter for SWD.) These results are available on request.

\section{Other macroeconomic variables}

When we control for happiness and then include a country's wealth (GDP p.c. 1974), the latter is negatively related to satisfaction. In other words, wealth does not independently increase SWD; to the contrary, for given happiness, richer countries are even less satisfied with the way democracy works. Without including happiness, GDP is, as expected, positively related to SWD. ${ }^{17}$

${ }^{17}$ In future versions of the paper, we will calculate marginal rates of subtitution between wealth and environmental quality. 
We cannot find robust statistical evidence for other macroeconomic variables like openness, debt, or the foreign exchange regime. Including these variables does not alter the substantial findings of our study. We therefore do not show these results.

\section{Variations in methods and samples}

Applying fixed instead of random effects does not change the substantive results. Leaving out all observations pertaining to Italy does not substantively change the results. As the raw data suggest, some of the relationships are weaker when Italy is excluded, because Italy has very low SWD and comparatively poor environmental quality and policy. But that does not make Italy an outlier - to the contrary, it is a prime example of the force a positive solution of collective action problems can have on SWD.

\section{The role of happiness}

Life satisfaction and satisfaction with democracy are closely related. We have proceeded under the assumption that happiness is an important determinant of satisfaction with democracy. Future work should go from positing this as an assumption towards determining the precise causal relationship between the two concepts. Very preliminary analysis using pooled vector autoregressions (VARs) suggests that while happiness has a positive influence on satisfaction, satisfaction has virtually no statistically significant influence on happiness. ${ }^{18}$ But precisely disentangling the relationship (insofar as this is possible) will have to await further research. The policy question of what is more important for regime support, satisfaction with democracy or more general life satisfaction is certainly an important one.

\footnotetext{
${ }^{18}$ More rigorous analysis, using panel VAR methods, is yet to be conducted.
} 


\section{Conclusion and policy implications}

This paper is, to our knowledge, the first study of the relationship between satisfaction with democracy and environmental quality and policy. We constructed a panel data set for 15 countries and 12 years. Although this provides us with only a limited number of observations, this empirical setting also provides the advantage over standard crosssectional studies of SWD because we here have an intertemporal dimension that allows us to in fact identify the effect of institutions and environmental variables on SWD. The drawback of the method in this paper is that we are not able to make individual-level inferences or other statements about how the average effects on SWD are distributed across the population.

Given the small sample size it is extraordinary that we are able to detect any effects. The strongest regularities, which hold up even when including a large set of other control variables are the following: Average SWD is higher where (1) there exists an energy / CO2 tax, where (2) certain environmental regulations like packaging rules are in place, where (3) government expenditures on the environment are higher and (4) where the government puts in place environmental offices or other official bodies charged with addressing environmental concerns. However, citizens appear to strongly dislike the existence of nature conservancy acts. We also find that, on the environmental quality side, (5) more cars on the roads, (6) less unleaded fuel, and (7) higher pesticide use intensity all decrease SWD. Perhaps not surprisingly, at the level of aggregation of this dataset, we cannot detect detrimental effects of emissions of various pollutants.

Since the dependent variable is average SWD, we are not able to make too strong policy recommendations because of the possibility that certain groups in society would be 
harmed despite a general increase in SWD, and that these groups may sometimes be the most powerful. Thus, implementing the changes that this paper has identified as increasing SWD on average, may take more than the majority of voters. But the findings of this paper establish that environmental issues play an important role for citizens' perceptions of the way the democracy in their countries works.

6 


\section{$\underline{\text { Appendix }}$}

\subsection{Data sources}

\subsubsection{Satisfaction with democracy}

Data on satisfaction with democracy and happiness comes from the Eurobarometer. So does information on ideological preferences.

\subsubsection{Environmental quality and policy}

Detailed data description regarding the environmental quality variables is contained in a separate appendix currently under revision. It will be available on request.

Details on the environmental policy variables used in this study can be found in Busch and Jörgens (2002), Tews (2002), Tews et al. (2002) and in particular in Binder (2002).

\subsubsection{BERI}

The Business Environment Risk Intelligence (BERI) data package covers 53 countries from 1980-2000. The countries covered include: Argentina, Australia, Austria, Belgium, Brazil, Canada, Chile, China (P.R.C.), Colombia, Czech Republic, Denmark, Ecuador, Egypt, Finland, France, Germany, Greece, Hungary, India, Indonesia, Iran, Ireland, Israel, Italy, Japan, Kazakhstan, Korea (South), Malaysia, Mexico, Morocco, Netherlands, Nigeria, Norway, Pakistan, Peru, Philippines, Poland, Portugal, Russia, Saudi Arabia, Singapore, South Africa, Spain, Sweden, Switzerland, Taiwan (R.O.C.), Thailand, Turkey, Ukraine, United Kingdom, United States, Venezuela, Vietnam.

BERI constructs three categories. The COMPOSITE INDEX that is used in this paper is an average of these factors.

The objective of ORI is to gauge the operations climate for foreign businesses. There are two variables being measured: (1) the degree to which nationals are given preferential treatment and (2) the general quality of the business climate, including bureaucratic and policy continuity. A permanent panel of 105 experts around the world rate present conditions for 15 criteria that measure the country's business environment from 0 (unacceptable conditions) to 4 (superior conditions). The following criteria have been used for over twenty years (weights are given in parentheses): Policy Continuity (3.0), Labor Cost/Productivity (2.0), Attitude: Foreign Investors and Profits (1.5), Professional Services and Contractors (0.5), Degree of Privatization (1.5), Communications and Transportation (1.0), Monetary Inflation (1.5), Balance of Payments (1.5), Local Management and Partners (1.0), Bureaucratic Delays (1.0), Economic Growth (2.5), Short-Term Credit (2.0), Currency Convertibility (2.5), Long-Term Loans and Venture Capital (2.0), Enforceability of Contracts (1.5). 
The Political Risk Index (PRI) focuses on sociopolitical conditions in a country. BERI utilizes a permanent panel of experts with diplomatic careers and training in a political science. The index is constructed in two steps. In the first step, the expert rates the present conditions for each of the 8 causes from 7 (no problems) to zero (prohibitive problems). These causes include:\ fractionalization of the political spectrum and the power of these factions; mentality, including xenophobia, nationalism, corruption, nepotism, willingness to compromise,etc.; fractionalization by language, ethnic and/or religious groups and the power of these factions; social conditions, including population density and wealth distribution; restrictive (coercive) measures required to retain power; organization and strength of forces for a radical government; dependence on and/or importance to a major hostile power; negative influences of regional political forces. Then, two symptoms are rated on the same scale in the present: societal conflict involving demonstrations, strikes, and street violence; instability as perceived by nonconstitutional changes, assassinations, and guerrilla wars. The perspective is from the viewpoint of an international bank rather than private enterprise owned by nationals. This subtotal involves a maximum of 70 for the perfect country. Since one or more of the causes may have an overwhelming impact on the overall political stability, the second subtotal of the system allocates a total of 30 points to causes (not symptoms) to reward especially advantageous situations. The expert can apply the points to one, two, etc., causes or opt to allocate no additional points. The lowest risk country could receive a rating of 100 as a result of steps one and two.

The purpose of the $\mathrm{R}$ (for remittances and repatriation of capital) Factor is to estimate a country's capacity and willingness for private foreign companies to convert profits and capital in the local currency to foreign exchange and transfer the funds and have access to convertible currency to import components, equipment, and raw materials. It consists of four subindices, the legal framework subindex, the foreign exchange generation subindex, the accumulated international reserves subindex, and the foreign debt assessment subindex. This index does not rely on experts but uses data like the IMF's International Financial Statistics, data on public foreign debt from the World Bank, etc. More detailed information is available from BERI and from the authors. 


\section{References}

Almond, G.A. and Verba, S. (1963). The civic culture: Political attitudes and democracy in five nations. Princeton, NJ: Princeton University Press.

Almond, G.A. and Verba, S. (eds.) (1980). The civic culture revisited: An analytical study. Boston, MA/Toronto: Little, Brown \& Co.

Anderson, C. and C. Guillory (1997). "Political Institutions and Satisfaction with Democracy: A Cross-National Analysis of Consensus and Majoritarian Systems.” American Political Science Review 91(March): 66-81.

Bennear, L., R. Stavins and A. Wagner (2005), "Using Revealed Preferences to Infer Environmental Benefits: Evidence from Recreational Fishing Licenses.” Journal of Regulatory Economics 28 (2): 157-179.

Busch, P.-O. and H. Jörgens (2002), “Globale Diffusionsmuster umweltpolitischer Innovationen.” Working Paper Freie Universität Berlin.

Clarke, H. D., et al. (1993). “The Political Economy of Attitudes toward Polity and Society in Western European Democracies.” Journal of Politics 55: 998-1021.

Easton, D. (1965). A System Analysis of Political Life. New York, McGraw Hill.

Easton, D. (1975). “A Re-Assessment of the Concept of Political Support.” British Journal of Political Science 5(October): 435-437.

Eurobarometer (EB) (various years). Available online at: http://europa.eu.int/comm/ public_opinion. Cologne: Zentralarchiv für Empirische Sozialforschung (http://www. gesis.org/ZA/).

Frey, B. and A. Stutzer (2002). "What can economists learn from happiness research?” Journal of Economic Literature 40(2): 402-435.

Israel D. and A. Levinson (2003), "Examining the Relationship between Household Satisfaction and Pollution”, Paper presented at the Eastern Economics Association Meetings, February 2003.

Klingemann, H.-D. and D. Fuchs (1995). Citizens and the State. New York, Oxford University Press. 
Linde, J. and J. Ekman (2003). "Satisfaction with democracy: A note on a frequently used indicator in comparative politics.” European Journal of Political Research 42: 391408.

Loomis, J.B., C. Pearce and M. Manfredo (2000), "Using the Demand for Hunting Licenses to Evaluate Contingent Valuation Estimates of Willingness-to-Pay.” Applied Economics Letters, 7: 435-438.

Lipset, S.M. (1959). Some social requisites of democracy: Economic development and political legitimacy. American Political Science Review 53: 69-105.

Rehdanz K. and D. Maddison (2005), “Climate and Happiness.” Ecological Economics, 52: $111-125$.

Tews, K., P.-O. Busch and H. Jörgens (2002), “The Diffusion of New Environmental Policy Instruments.” Working Paper Freie Universität Berlin.

Wagner, A. F. and F. Schneider (2005a). Institutions of conflict management and satisfaction with democracy in Western Europe, Department of Economics. Linz, University of Linz.

Wagner, A. F. and F. Schneider (2005b). The quality of institutions and satisfaction with democracy in Western Europe - a panel analysis, Department of Economics. Linz, University of Linz.

Wegmayr, J. (2005), “Survey Political Economy and Happiness," Working Paper University of Linz.

Welsch H. (2005). "Environment and Happiness: Valuation of Air Pollution in Ten European Countries”, forthcoming, Ecological Economics

Welsch, H. (2002). "Preferences over Prosperity and Pollution: Environmental Valuation Based on Happiness Surveys.” Kyklos 55: 473-495. 


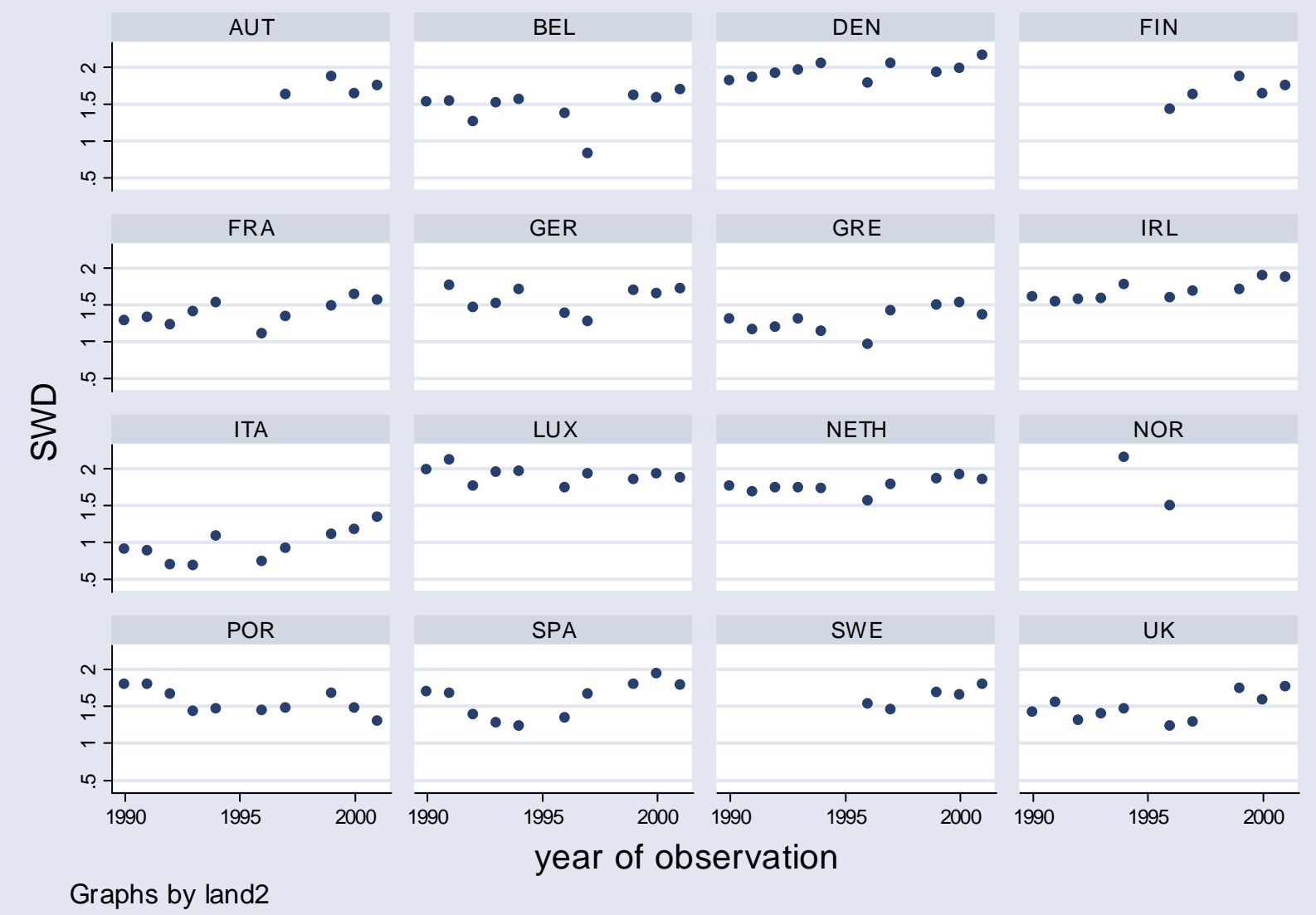

Figure 1: Trends in Satisfaction with Democracy, 1990-2001 


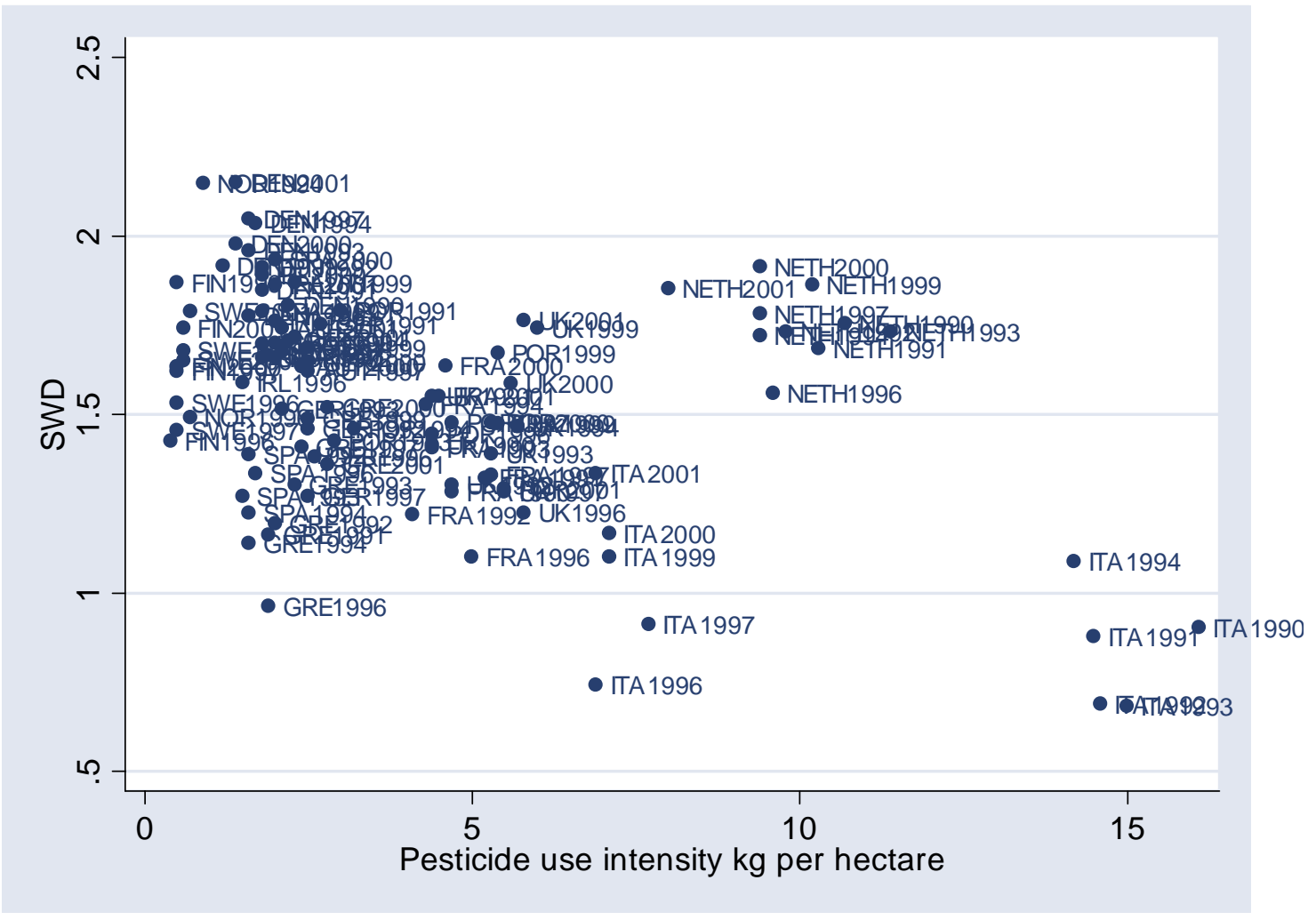

Figure 2: Pesticide use intensity and satisfaction with democracy 
Table 1: Descriptive statistics

15 EU countries, 1990-2001

\begin{tabular}{|c|c|c|c|c|c|c|}
\hline Variable & Source & Obs & Mean & Std. Dev. & Min & Max \\
\hline "Satisfaction with democracy & Eurostat & 13135 & 1.56 & 0.30 & 0.68 & 2.15 \\
\hline Happiness & Eurostat & 120 & 2.04 & 0.30 & 1.36 & 2.63 \\
\hline Unemployment & OECD & 136 & 8.01 & 3.57 & 1.26 & 18.44 \\
\hline Inflation (log) & OECD & 106 & 0.04 & 0.03 & 0.00 & 0.19 \\
\hline Renewable energy subsidies (REG-Strom) & Binder (2002), Busch and Jörgens (2002) & 134 & 0.09 & 0.29 & 0.00 & 1.00 \\
\hline Energy / CO2 tax & Binder (2002), Busch and Jörgens (2002) & 134 & 0.33 & 0.47 & 0.00 & 1.00 \\
\hline Packaging rules & Binder (2002), Busch and Jörgens (2002) & 134 & 0.43 & 0.50 & 0.00 & 1.00 \\
\hline Sustainability council & Binder (2002), Busch and Jörgens (2002) & 134 & 0.34 & 0.48 & 0.00 & 1.00 \\
\hline Subsidy for renewable energy & Binder (2002), Busch and Jörgens (2002) & 134 & 0.54 & 0.50 & 0.00 & 1.00 \\
\hline Energy efficiency labels & Binder (2002), Busch and Jörgens (2002) & 134 & 0.62 & 0.49 & 0.00 & 1.00 \\
\hline Environmental plan & Binder (2002), Busch and Jörgens (2002) & 134 & 0.54 & 0.50 & 0.00 & 1.00 \\
\hline Environmental labels & Binder (2002), Busch and Jörgens (2002) & 134 & 0.85 & 0.36 & 0.00 & 1.00 \\
\hline Environmental protection plan & Binder (2002), Busch and Jörgens (2002) & 134 & 0.95 & 0.22 & 0.00 & 1.00 \\
\hline Environmental information act & Binder (2002), Busch and Jörgens (2002) & 134 & 0.78 & 0.41 & 0.00 & 1.00 \\
\hline Environmental office & Binder (2002), Busch and Jörgens (2002) & 134 & 0.72 & 0.45 & 0.00 & 1.00 \\
\hline Environmental expert council & Binder (2002), Busch and Jörgens (2002) & 134 & 0.87 & 0.34 & 0.00 & 1.00 \\
\hline General environmental act & Binder (2002), Busch and Jörgens (2002) & 134 & 0.51 & 0.50 & 0.00 & 1.00 \\
\hline Environmental reporting rules & Binder (2002), Busch and Jörgens (2002) & 134 & 0.82 & 0.38 & 0.00 & 1.00 \\
\hline Garbage law & Binder (2002), Busch and Jörgens (2002) & 134 & 0.93 & 0.26 & 0.00 & 1.00 \\
\hline Environmental protection as a constitutional goal & Binder (2002), Busch and Jörgens (2002) & 134 & 0.50 & 0.50 & 0.00 & 1.00 \\
\hline Ministry of the environment & Binder (2002), Busch and Jörgens (2002) & 134 & 0.96 & 0.19 & 0.00 & 1.00 \\
\hline Nature conservancy act & Binder (2002), Busch and Jörgens (2002) & 134 & 0.80 & 0.40 & 0.00 & 1.00 \\
\hline Water protection act & Binder (2002), Busch and Jörgens (2002) & 134 & 1.00 & 0.00 & 1.00 & 1.00 \\
\hline Ground protection act & Binder (2002), Busch and Jörgens (2002) & 134 & 0.39 & 0.49 & 0.00 & 1.00 \\
\hline Air protection act & Binder (2002), Busch and Jörgens (2002) & 134 & 1.00 & 0.00 & 1.00 & 1.00 \\
\hline Environmental policy (sum of all measures) & Own calculation based on Binder (2002) & 134 & 13.98 & 3.54 & 4.00 & 21.00 \\
\hline Government expenditures on the environment p.c. & Eurostat & 79 & 135.22 & 92.61 & 21.53 & 413.16 \\
\hline Government expenditures on the environment in percent of GDP & Eurostat & 78 & 0.01 & 0.00 & 0.00 & 0.01 \\
\hline Environmental taxes in percent of GDP & Eurostat & 134 & 0.08 & 0.41 & 0.02 & 3.48 \\
\hline
\end{tabular}


Table 1: Descriptive statistics (continued)

15 EU countries, 1990-2001

\begin{tabular}{|c|c|c|c|c|c|c|}
\hline Variable & Source & Obs & Mean & Std. Dev. & Min & Max \\
\hline Transportation: Passenger cars per 1000 people & World Resources Institute & 98 & 374.76 & 101.29 & 162.20 & 586.60 \\
\hline Agricultural inputs: fertilizer use intensity; kilograms per hectare & World Resources Institute & 116 & 252.33 & 175.61 & 76.90 & 739.40 \\
\hline Agricultural inputs: pesticide use intensity (kg per hectare) & World Resources Institute & 109 & 4.13 & 3.55 & 0.40 & 16.10 \\
\hline Agricultural yields: cereals, yields, kilograms per hectare & World Resources Institute & 118 & 5173.65 & 1732.37 & 1779.00 & 8292.90 \\
\hline Land: arable and permanent cropland, hectares per capita & World Resources Institute & 103 & 0.28 & 0.14 & 0.06 & 0.52 \\
\hline Wood fuel production (cubic meters per capita) & World Resources Institute & 112 & 0.11 & 0.18 & 0.00 & 0.80 \\
\hline Recovered paper (kg per capita) & World Resources Institute & 105 & 73.52 & 45.68 & 4.10 & 186.75 \\
\hline Roundwood, total; cubic meters per person & World Resources Institute & 105 & 1.10 & 2.19 & 0.06 & 10.47 \\
\hline Sawnwood; cubic meters per person per year & World Resources Institute & 105 & 0.29 & 0.54 & 0.01 & 2.59 \\
\hline Organic pollutant emissions (kilograms per day per capita) & World Resources Institute & 121 & 0.01 & 0.00 & 0.00 & 0.02 \\
\hline Agricultural Workers (percent of total labor force) & World Resources Institute & 136 & 6.88 & 5.33 & 1.70 & 23.00 \\
\hline Paper and paperboard consumption per capita; kg/person/year & World Resources Institute & 122 & 179.52 & 75.00 & 56.01 & 431.74 \\
\hline CO2 index & Tews and Binder (2002) & 105 & 105.85 & 15.16 & 42.00 & 145.00 \\
\hline CO2 Emissions & OECD & 90 & 9.61 & 5.00 & 4.30 & 27.60 \\
\hline SOx Emissions (tons per capita) & OECD & 105 & 0.03 & 0.02 & 0.00 & 0.07 \\
\hline NOx Emissions (tons per capita) & OECD & 105 & 0.04 & 0.01 & 0.00 & 0.06 \\
\hline Emissions of particulates (tons per capita) & OECD & 40 & 0.01 & 0.01 & 0.00 & 0.03 \\
\hline CO Emissions (tons per capita) & OECD & 105 & 0.12 & 0.07 & 0.00 & 0.55 \\
\hline VOC emissions (tons per capita) & OECD & 97 & 0.04 & 0.01 & 0.02 & 0.08 \\
\hline CO2 Emissions from energy use (tons per capita) & OECD & 106 & 9.68 & 4.78 & 4.05 & 28.21 \\
\hline Waste recycling rates: paper and cardboard & OECD & 109 & 41.96 & 14.23 & 10.00 & 73.00 \\
\hline Waste recycling rates: glass & OECD & 105 & 50.77 & 21.40 & 15.00 & 91.00 \\
\hline Nuclear waste: spent fuel arisings (tons of $\mathrm{HM}$ ) & OECD & 43 & 292.84 & 241.02 & 68.00 & 997.00 \\
\hline Roads (m per capita) & OECD & 108 & 11.05 & 6.18 & 3.91 & 26.26 \\
\hline Domestic consumption of energy to GDP, kgoe per 1000 Euro & Eurostat & 117 & 221.72 & 37.88 & 125.00 & 305.00 \\
\hline Energy use by traffic in \% of total & Eurostat & 89 & 35.67 & 6.68 & 19.60 & 52.20 \\
\hline Petrol unleaded in \% of total petrol & Eurostat & 104 & 56.55 & 30.71 & 0.90 & 100.00 \\
\hline Municipal waste, kg per person per year & Eurostat & 87 & 504.66 & 91.88 & 304.41 & 665.29 \\
\hline Renewable energy in \% of total power consumption & Eurostat & 112 & 15.92 & 19.53 & 1.00 & 99.50 \\
\hline
\end{tabular}


Table 2: Correlations between the most important variables

15 EU countries, 1990-2001

\begin{tabular}{|c|c|c|c|c|c|c|c|c|c|c|c|c|c|c|c|c|c|c|c|c|c|c|c|c|c|c|}
\hline & 1 & 2 & 3 & 4 & 5 & 6 & 7 & 8 & 9 & 10 & 11 & 12 & 13 & 14 & 15 & 16 & 17 & 18 & 19 & 20 & 21 & 22 & 23 & 24 & 25 & 26 \\
\hline 1 SWD & 1.00 & & & & & & & & & & & & & & & & & & & & & & & & & \\
\hline 2 HAPPINESS & 0.67 & 1.00 & & & & & & & & & & & & & & & & & & & & & & & & \\
\hline 3 UNEMPLOY & -0.47 & -0.39 & 1.00 & & & & & & & & & & & & & & & & & & & & & & & \\
\hline 4 INFLATION & -0.28 & -0.48 & -0.05 & 1.00 & & & & & & & & & & & & & & & & & & & & & & \\
\hline 5 ENVPOLICY & 0.20 & 0.06 & -0.21 & -0.25 & 1.00 & & & & & & & & & & & & & & & & & & & & & \\
\hline 6 ENVTAXPERC & 0.08 & 0.02 & 0.11 & -0.10 & 0.11 & 1.00 & & & & & & & & & & & & & & & & & & & & \\
\hline 7 ENVGOVPC & 0.55 & 0.62 & -0.20 & -0.29 & 0.17 & -0.06 & 1.00 & & & & & & & & & & & & & & & & & & & \\
\hline 8 ENVGOVPERC & 0.35 & 0.33 & -0.01 & 0.05 & 0.04 & -0.11 & 0.83 & 1.00 & & & & & & & & & & & & & & & & & & \\
\hline 9 LAWNATURE & 0.23 & 0.07 & -0.15 & -0.07 & 0.16 & 0.06 & 0.24 & 0.34 & 1.00 & & & & & & & & & & & & & & & & & \\
\hline 10 ENVMIN & 0.07 & 0.12 & -0.34 & -0.12 & 0.32 & 0.03 & 0.06 & -0.03 & -0.10 & 1.00 & & & & & & & & & & & & & & & & \\
\hline 11 ENVCONST & 0.01 & -0.35 & 0.06 & 0.24 & 0.33 & 0.12 & -0.48 & -0.32 & 0.24 & -0.20 & 1.00 & & & & & & & & & & & & & & & \\
\hline 12 ENVOFFICE & -0.01 & -0.04 & -0.11 & 0.06 & 0.64 & 0.08 & 0.19 & 0.23 & -0.06 & 0.32 & 0.05 & 1.00 & & & & & & & & & & & & & & \\
\hline 13 SUSTAIN & 0.09 & 0.00 & -0.15 & -0.35 & 0.53 & 0.17 & -0.29 & -0.51 & 0.09 & 0.14 & 0.25 & 0.20 & 1.00 & & & & & & & & & & & & & \\
\hline 14 PACK & 0.12 & 0.01 & -0.04 & -0.40 & 0.47 & 0.14 & -0.18 & -0.40 & -0.01 & 0.17 & 0.09 & 0.17 & 0.57 & 1.00 & & & & & & & & & & & & \\
\hline 15 ENVTAX & 0.28 & 0.37 & -0.17 & -0.34 & 0.54 & 0.18 & 0.26 & -0.06 & 0.07 & 0.14 & 0.32 & 0.18 & 0.47 & 0.32 & 1.00 & & & & & & & & & & & \\
\hline $16 \mathrm{CO} 2$ & 0.48 & 0.52 & -0.53 & -0.25 & -0.22 & 0.04 & 0.65 & 0.36 & 0.22 & 0.20 & -0.35 & -0.34 & -0.09 & -0.12 & 0.05 & 1.00 & & & & & & & & & & \\
\hline 17 AGRWORK & -0.25 & -0.58 & 0.27 & 0.71 & -0.13 & -0.02 & -0.35 & 0.06 & -0.26 & -0.14 & 0.32 & 0.12 & -0.32 & -0.41 & -0.39 & -0.41 & 1.00 & & & & & & & & & \\
\hline 18 ROADS & 0.34 & 0.42 & 0.05 & -0.46 & -0.07 & 0.10 & 0.25 & -0.09 & -0.33 & 0.25 & -0.34 & -0.06 & 0.28 & 0.17 & 0.20 & 0.20 & -0.16 & 1.00 & & & & & & & & \\
\hline 19 PESTIZIDE & -0.43 & -0.04 & -0.10 & 0.01 & -0.03 & -0.14 & -0.15 & -0.09 & -0.28 & 0.15 & -0.20 & -0.09 & -0.07 & -0.18 & -0.09 & -0.03 & -0.17 & -0.33 & 1.00 & & & & & & & \\
\hline 20 OPE & 0.37 & 0.36 & -0.30 & -0.16 & -0.14 & 0.06 & 0.08 & 0.07 & 0.01 & 0.08 & -0.21 & -0.05 & -0.21 & -0.11 & -0.12 & 0.50 & -0.08 & 0.20 & -0.24 & 1.00 & & & & & & \\
\hline 21 RECPAP & 0.29 & 0.17 & -0.29 & -0.31 & 0.50 & 0.20 & 0.11 & -0.17 & 0.41 & 0.07 & 0.49 & 0.17 & 0.38 & 0.45 & 0.59 & 0.26 & -0.45 & -0.13 & -0.14 & -0.03 & 1.00 & & & & & \\
\hline 22 RECGL & 0.29 & 0.44 & -0.41 & -0.55 & 0.50 & 0.13 & 0.19 & -0.18 & 0.16 & 0.24 & 0.24 & 0.15 & 0.47 & 0.47 & 0.73 & 0.44 & -0.63 & 0.21 & 0.10 & -0.08 & 0.74 & 1.00 & & & & \\
\hline 23 sox & -0.21 & -0.30 & 0.36 & 0.50 & -0.50 & -0.10 & -0.17 & 0.18 & -0.04 & -0.31 & -0.09 & -0.08 & -0.44 & -0.44 & -0.52 & -0.22 & 0.51 & -0.17 & -0.24 & -0.05 & -0.60 & -0.82 & 1.00 & & & \\
\hline $24 \mathrm{NOX}$ & 0.26 & 0.38 & -0.07 & -0.07 & 0.04 & 0.20 & 0.46 & 0.42 & 0.20 & 0.06 & -0.20 & 0.02 & -0.13 & -0.27 & 0.12 & 0.16 & -0.09 & 0.12 & -0.21 & 0.32 & -0.09 & -0.05 & 0.22 & 1.00 & & \\
\hline 25 PARTICULATE & 0.16 & 0.06 & 0.07 & -0.04 & -0.46 & 0.14 & -0.24 & -0.41 & -0.50 & & -0.14 & -0.36 & -0.05 & -0.08 & -0.03 & 0.01 & 0.69 & 0.68 & -0.39 & -0.18 & 0.00 & -0.09 & 0.33 & 0.22 & 1.00 & \\
\hline 26 UNLEAD & 0.42 & 0.47 & -0.29 & -0.66 & 0.60 & 0.20 & 0.43 & 0.08 & 0.26 & 0.35 & 0.01 & 0.31 & 0.48 & 0.55 & 0.60 & 0.36 & -0.59 & 0.30 & -0.22 & 0.12 & 0.64 & 0.77 & -0.56 & 0.09 & -0.15 & \\
\hline
\end{tabular}

The variables are as follows: (1) Satisfaction with democracy, (2) Life satisfaction, (3) Unemployment, (4) Log inflation, (5) Environmental policy (sum of all measures)

(6) Environmental taxes in percent of GDP, (7) Government expenditures on the environment per capita, (8) Government expenditures on the environment in percent of GDP

9) Nature conservancy act, (10) Environmental ministry, (11) Environment in the constitution, (12) Environmental office, (13) Sustainability council

(14) Packaging regulation, (15) Energy or CO2 tax, (16) CO2 emissions, (17) Agricultural work force), (18) Roads, (19) Pesticide use, (20), Organic pollutants

(21) Paper recycling, (22) Glass recycling, (23) SOx emissions, (24) NOx emissions, (25) Particulate emissions, (26) Unleaded fuel 
Table 3: Satisfaction with democracy and environmental policy

Dependent variable: Average yearly satisfaction with democracy: $1=$ not at all satisfied, $4=$ very satisfied

Random effects panel regressions

\begin{tabular}{|c|c|c|c|c|c|c|c|c|c|c|c|c|}
\hline & $(1)$ & $(2)$ & $(3)$ & $(4)$ & $(5)$ & $(6)$ & $(7)$ & $(8)$ & $(9)$ & $(10)$ & $(11)$ & $(12)$ \\
\hline Happiness & $\begin{array}{c}0.586 \\
(4.94)^{\star *}\end{array}$ & $\begin{array}{c}0.574 \\
(4.82)^{\star \star}\end{array}$ & $\begin{array}{c}0.652 \\
(5.16)^{\star \star}\end{array}$ & $\begin{array}{c}0.626 \\
(5.06)^{\star *}\end{array}$ & $\begin{array}{c}0.578 \\
(4.82)^{\star *}\end{array}$ & $\begin{array}{c}0.637 \\
(5.20)^{\star *}\end{array}$ & $\begin{array}{c}0.574 \\
(4.85)^{\star *}\end{array}$ & $\begin{array}{c}0.564 \\
(4.72)^{\star \star}\end{array}$ & $\begin{array}{c}0.473 \\
(3.28)^{\star \star}\end{array}$ & $\begin{array}{c}0.454 \\
(3.18)^{\star \star}\end{array}$ & $\begin{array}{c}0.556 \\
(4.67)^{\star *}\end{array}$ & $\begin{array}{c}0.651 \\
(5.16)^{\star *}\end{array}$ \\
\hline Unemployment & $\begin{array}{l}-0.021 \\
(2.48)^{\star}\end{array}$ & $\begin{array}{l}-0.021 \\
(2.51)^{\star}\end{array}$ & $\begin{array}{l}-0.015 \\
(1.75)\end{array}$ & $\begin{array}{c}-0.016 \\
(1.84)\end{array}$ & $\begin{array}{l}-0.020 \\
(2.35)^{*}\end{array}$ & $\begin{array}{c}-0.022 \\
(2.62)^{\star \star}\end{array}$ & $\begin{array}{l}-0.018 \\
(2.21)^{*}\end{array}$ & $\begin{array}{l}-0.021 \\
(2.54)^{\star}\end{array}$ & $\begin{array}{c}-0.020 \\
(1.51)\end{array}$ & $\begin{array}{l}-0.027 \\
(2.03)^{\star}\end{array}$ & $\begin{array}{l}-0.021 \\
(2.50)^{*}\end{array}$ & $\begin{array}{l}-0.018 \\
(2.14)^{*}\end{array}$ \\
\hline Inflation (log) & $\begin{array}{l}-1.726 \\
(2.69)^{\star \star}\end{array}$ & $\begin{array}{l}-1.492 \\
(2.33)^{\star}\end{array}$ & $\begin{array}{l}-1.152 \\
(1.67)\end{array}$ & $\begin{array}{l}-1.303 \\
(1.94)\end{array}$ & $\begin{array}{l}-1.522 \\
(2.35)^{\star}\end{array}$ & $\begin{array}{l}-1.619 \\
(2.56)^{\star}\end{array}$ & $\begin{array}{l}-1.430 \\
(2.21)^{\star}\end{array}$ & $\begin{array}{l}-2.111 \\
(3.17)^{\star \star}\end{array}$ & $\begin{array}{c}-2.996 \\
(3.48)^{\star \star}\end{array}$ & $\begin{array}{l}-3.619 \\
(4.29)^{\star \star}\end{array}$ & $\begin{array}{l}-1.628 \\
(2.53)^{\star}\end{array}$ & $\begin{array}{l}-0.856 \\
(1.12)\end{array}$ \\
\hline Environmental policy (sum of all measures) & & & & & & & & & & & & $\begin{array}{l}0.014 \\
(1.94)\end{array}$ \\
\hline Environmental taxes in percent of GDP & & & & & & & & & & & $\begin{array}{l}0.065 \\
(0.98)\end{array}$ & \\
\hline Government expenditures on the environment in percent of GDP & & & & & & & & & & $\begin{array}{l}25.410 \\
(2.06)^{\star}\end{array}$ & & \\
\hline Government expenditures on the environment p.c. & & & & & & & & & $\begin{array}{l}0.001 \\
(1.81)\end{array}$ & & & \\
\hline Nature conservancy act & & & & & & & & $\begin{array}{l}-0.168 \\
(1.94)\end{array}$ & & & & \\
\hline Ministry of the environment & & & & & & & $\begin{array}{l}0.197 \\
(1.85)\end{array}$ & & & & & \\
\hline Environmental protection as a constitutional goal & & & & & & $\begin{array}{c}0.134 \\
(2.03)^{\star}\end{array}$ & & & & & & \\
\hline Environmental office & & & & & $\begin{array}{l}0.092 \\
(1.55)\end{array}$ & & & & & & & \\
\hline Sustainability council & & & & $\begin{array}{l}0.085 \\
(1.73)\end{array}$ & & & & & & & & \\
\hline Packaging rules & & & $\begin{array}{l}0.086 \\
(1.94)\end{array}$ & & & & & & & & & \\
\hline Energy / CO2 tax & & $\begin{array}{l}0.098 \\
(1.96)\end{array}$ & & & & & & & & & & \\
\hline Constant & $\begin{array}{c}0.606 \\
(2.16)^{*}\end{array}$ & $\begin{array}{c}0.576 \\
(2.06)^{\star}\end{array}$ & $\begin{array}{l}0.355 \\
(1.15)\end{array}$ & $\begin{array}{l}0.429 \\
(1.43)\end{array}$ & $\begin{array}{l}0.526 \\
(1.84)\end{array}$ & $\begin{array}{l}0.421 \\
(1.44)\end{array}$ & $\begin{array}{l}0.400 \\
(1.32)\end{array}$ & $\begin{array}{c}0.783 \\
(2.68)^{\star \star}\end{array}$ & $\begin{array}{c}0.734 \\
(2.05)^{\star}\end{array}$ & $\begin{array}{c}0.794 \\
(2.26)^{\star}\end{array}$ & $\begin{array}{c}0.638 \\
(2.29)^{\star}\end{array}$ & $\begin{array}{l}0.221 \\
(0.64)\end{array}$ \\
\hline Observations & 90 & 89 & 89 & 89 & 89 & 89 & 89 & 89 & 51 & 51 & 89 & 89 \\
\hline Number of Countries & 16 & 15 & 15 & 15 & 15 & 15 & 15 & 15 & 14 & 14 & 15 & 15 \\
\hline
\end{tabular}


Table 4: Satisfaction with democracy and environmental quality

Dependent variable: Average yearly satisfaction with democracy: $1=$ not at all satisfied, 4 = very satisfied

Random effects panel regressions

\begin{tabular}{|c|c|c|c|c|c|c|c|c|c|c|c|c|}
\hline & $(1)$ & $(2)$ & (3) & $(4)$ & $(5)$ & (6) & $(7)$ & (8) & $(9)$ & $(10)$ & $(11)$ & $(12)$ \\
\hline Happiness & $\begin{array}{c}0.628 \\
(5.26)^{\star \star}\end{array}$ & $\begin{array}{c}0.530 \\
(4.33)^{\star \star}\end{array}$ & $\begin{array}{c}0.479 \\
(3.68)^{\star \star}\end{array}$ & $\begin{array}{c}0.464 \\
(4.18)^{\star \star}\end{array}$ & $\begin{array}{c}0.591 \\
(4.95)^{\star \star}\end{array}$ & $\begin{array}{c}0.666 \\
(5.19)^{\star \star}\end{array}$ & $\begin{array}{c}0.598 \\
(4.75)^{\star \star}\end{array}$ & $\begin{array}{c}0.597 \\
(4.66)^{\star \star}\end{array}$ & $\begin{array}{c}0.590 \\
(4.64)^{\star \star}\end{array}$ & $\begin{array}{c}0.819 \\
(4.25)^{\star \star}\end{array}$ & $\begin{array}{c}0.553 \\
(4.20)^{\star \star}\end{array}$ & $\begin{array}{c}0.616 \\
(5.07)^{\star \star}\end{array}$ \\
\hline Unemployment & $\begin{array}{c}-0.024 \\
(2.83)^{\star *}\end{array}$ & $\begin{array}{l}-0.025 \\
(2.44)^{*}\end{array}$ & $\begin{array}{l}-0.026 \\
(2.47)^{\star}\end{array}$ & $\begin{array}{c}-0.027 \\
(3.09)^{\star *}\end{array}$ & $\begin{array}{l}-0.021 \\
(2.49)^{\star}\end{array}$ & $\begin{array}{l}-0.017 \\
(1.85)\end{array}$ & $\begin{array}{l}-0.018 \\
(1.86)\end{array}$ & $\begin{array}{l}-0.018 \\
(2.02)^{\star}\end{array}$ & $\begin{array}{l}-0.019 \\
(2.22)^{\star}\end{array}$ & $\begin{array}{l}-0.028 \\
(1.74)\end{array}$ & $\begin{array}{l}-0.020 \\
(1.73)\end{array}$ & $\begin{array}{l}-0.015 \\
(1.69)\end{array}$ \\
\hline Inflation (log) & $\begin{array}{c}-2.660 \\
(2.99)^{\star \star}\end{array}$ & $\begin{array}{l}-2.194 \\
(2.19)^{\star}\end{array}$ & $\begin{array}{l}-1.851 \\
(1.79)\end{array}$ & $\begin{array}{c}-2.316 \\
(3.49)^{\star \star}\end{array}$ & $\begin{array}{c}-1.676 \\
(2.59)^{\star \star}\end{array}$ & $\begin{array}{l}-1.257 \\
(1.80)\end{array}$ & $\begin{array}{l}-1.427 \\
(1.89)\end{array}$ & $\begin{array}{c}-1.101 \\
(1.33)\end{array}$ & $\begin{array}{l}-1.393 \\
(1.86)\end{array}$ & $\begin{array}{c}-4.768 \\
(3.15)^{\star \star}\end{array}$ & $\begin{array}{l}-1.001 \\
(1.20)\end{array}$ & $\begin{array}{c}-0.538 \\
(0.60)\end{array}$ \\
\hline Petrol unleaded in $\%$ of total petrol & & & & & & & & & & & & $\begin{array}{l}0.002 \\
(1.82)\end{array}$ \\
\hline CO2 Emissions & & & & & & & & & & & $\begin{array}{l}0.000 \\
(0.04)\end{array}$ & \\
\hline Emissions of particulates (tons per capita) & & & & & & & & & & $\begin{array}{l}4.212 \\
(0.52)\end{array}$ & & \\
\hline NOx Emissions (tons per capita) & & & & & & & & & $\begin{array}{l}-1.620 \\
(0.86)\end{array}$ & & & \\
\hline SOx Emissions (tons per capita) & & & & & & & & $\begin{array}{c}-1.886 \\
(1.07)\end{array}$ & & & & \\
\hline Waste recycling rates: glass & & & & & & & $\begin{array}{l}0.000 \\
(0.24)\end{array}$ & & & & & \\
\hline Waste recycling rates: paper and cardboard & & & & & & $\begin{array}{c}0.005 \\
(1.98)^{*}\end{array}$ & & & & & & \\
\hline Organic pollutant emissions (kilograms per day per capita) & & & & & $\begin{array}{l}-2.624 \\
(0.48)\end{array}$ & & & & & & & \\
\hline Agricultural inputs: pesticide use intensity (kg per hectare) & & & & $\begin{array}{c}-0.032 \\
(3.67)^{\star \star}\end{array}$ & & & & & & & & \\
\hline Transportation: Passenger cars per 1000 people & & $\begin{array}{l}-0.001 \\
(1.61)\end{array}$ & $\begin{array}{c}-0.001 \\
(1.46)\end{array}$ & & & & & & & & & \\
\hline Roads (m per capita) & & & $\begin{array}{l}0.010 \\
(1.23)\end{array}$ & & & & & & & & & \\
\hline Agricultural Workers (percent of total labor force) & $\begin{array}{l}0.018 \\
(1.59)\end{array}$ & & & & & & & & & & & \\
\hline Constant & $\begin{array}{l}0.450 \\
(1.53)\end{array}$ & $\begin{array}{c}1.075 \\
(2.64)^{\star \star}\end{array}$ & $\begin{array}{c}1.026 \\
(2.50)^{\star}\end{array}$ & $\begin{array}{c}1.050 \\
(3.88)^{\star \star}\end{array}$ & $\begin{array}{c}0.622 \\
(2.23)^{\star}\end{array}$ & $\begin{array}{l}0.156 \\
(0.44)\end{array}$ & $\begin{array}{l}0.511 \\
(1.52)\end{array}$ & $\begin{array}{c}0.588 \\
(1.99)^{\star}\end{array}$ & $\begin{array}{c}0.629 \\
(2.17)^{\star}\end{array}$ & $\begin{array}{l}0.174 \\
(0.38)\end{array}$ & $\begin{array}{l}0.614 \\
(1.90)\end{array}$ & $\begin{array}{l}0.334 \\
(1.04)\end{array}$ \\
\hline Observations & 90 & 82 & 82 & 70 & 90 & 81 & 77 & 85 & 85 & 31 & 75 & 89 \\
\hline Number of Country Number & 16 & 16 & 16 & 14 & 16 & 15 & 15 & 16 & 16 & 10 & 16 & 15 \\
\hline
\end{tabular}


Table 5: Robustness tests for environmental policy indicators

Dependent variable: Average yearly satisfaction with democracy: $1=$ not at all satisfied, 4 = very satisfied Random effects panel regressions

\begin{tabular}{|c|c|c|c|c|c|c|c|c|c|c|c|c|c|c|}
\hline & $(1)$ & $(2)$ & (3) & $(4)$ & (5) & (6) & $(7)$ & (8) & (9) & $(10)$ & (11) & $(12)$ & $(13)$ & $(14)$ \\
\hline \multirow[t]{2}{*}{ Happiness } & 0.682 & 0.389 & 0.723 & 0.697 & 0.690 & 0.435 & 0.678 & 0.776 & 0.576 & 0.513 & 0.431 & 0.413 & 0.621 & 0.553 \\
\hline & $(4.06)^{\star \star}$ & $(1.74)$ & $(5.30)^{\star \star}$ & $(4.41)^{\star \star}$ & $(4.40)^{\star \star}$ & $(2.25)^{\star}$ & $(4.26)^{\star \star}$ & $(5.37)^{\star \star}$ & $(4.96)^{\star \star}$ & $(4.67)^{\star \star}$ & $(3.24)^{\star \star}$ & $(3.21)^{\star \star}$ & $(5.40)^{\star \star}$ & $(4.96)^{\star \star}$ \\
\hline \multirow[t]{2}{*}{ Unemployment } & -0.006 & -0.021 & & -0.007 & -0.011 & -0.023 & -0.010 & & 0.008 & 0.010 & 0.009 & 0.011 & 0.004 & 0.008 \\
\hline & $(0.62)$ & $(1.23)$ & & $(0.74)$ & $(1.17)$ & $(1.57)$ & $(1.05)$ & & (1.67) & $(2.04)^{\star}$ & $(1.47)$ & (1.86) & $(0.77)$ & $(1.57)$ \\
\hline \multirow[t]{2}{*}{ Inflation (log) } & -0.500 & -2.342 & & -0.277 & -0.794 & -2.267 & -0.507 & & -0.158 & -0.168 & -0.131 & -0.159 & -0.134 & -0.151 \\
\hline & $(0.54)$ & $(1.82)$ & & $(0.32)$ & $(0.89)$ & $(1.80)$ & $(0.57)$ & & $(4.24)^{\star \star}$ & $(4.64)^{\star \star}$ & $(2.50)^{*}$ & $(3.20)^{\star \star}$ & $(3.47)^{\star \star}$ & $(4.00)^{\star \star}$ \\
\hline BERI Composite Index & $\begin{array}{l}0.003 \\
(0.45)\end{array}$ & $\begin{array}{l}0.003 \\
(0.37)\end{array}$ & $\begin{array}{l}0.001 \\
(0.12)\end{array}$ & & & & & $\begin{array}{l}0.001 \\
(0.19)\end{array}$ & & & & & & \\
\hline Ideological diversity & & & & & & & & & $\begin{array}{l}-0.158 \\
(4.24)^{\star \star}\end{array}$ & $\begin{array}{l}-0.168 \\
(4.64)^{\star \star}\end{array}$ & $\begin{array}{l}-0.131 \\
(2.50)^{*}\end{array}$ & $\begin{array}{l}-0.159 \\
(3.20)^{\star \star}\end{array}$ & $\begin{array}{l}-0.134 \\
(3.47)^{\star \star}\end{array}$ & $\begin{array}{l}-0.151 \\
(4.00)^{\star \star}\end{array}$ \\
\hline Energy / CO2 tax & & & & & & & $\begin{array}{l}0.079 \\
(1.42)\end{array}$ & $\begin{array}{l}0.068 \\
(1.40)\end{array}$ & & & & & & $\begin{array}{l}0.062 \\
(1.34)\end{array}$ \\
\hline Packaging rules & & & $\begin{array}{l}0.076 \\
(1.50)\end{array}$ & & & & & & & & & & $\begin{array}{c}0.099 \\
(2.27)^{\star}\end{array}$ & \\
\hline Government expenditures on environment in $\%$ of GDP & & $\begin{array}{c}24.919 \\
(1.81)\end{array}$ & & & & $\begin{array}{l}25.973 \\
(2.01)^{\star}\end{array}$ & & & & & & $\begin{array}{l}22.712 \\
(2.10)^{*}\end{array}$ & & \\
\hline Government expenditures on the environment p.c. & & & & & & & & & & & $\begin{array}{l}0.001 \\
(1.53)\end{array}$ & & & \\
\hline Nature conservancy act & $\begin{array}{l}-0.188 \\
(2.18)^{*}\end{array}$ & & & & $\begin{array}{l}-0.191 \\
(2.25)^{\star}\end{array}$ & & & & & $\begin{array}{l}-0.146 \\
(1.92)\end{array}$ & & & & \\
\hline Environmental office & & & & $\begin{array}{l}0.077 \\
(1.24)\end{array}$ & & & & & & & & & & \\
\hline Environmental protection as a constitutional goal & & & & & & & & & $\begin{array}{l}0.080 \\
(1.29)\end{array}$ & & & & & \\
\hline Constant & $\begin{array}{l}0.187 \\
(0.37)\end{array}$ & $\begin{array}{l}0.632 \\
(0.95)\end{array}$ & $\begin{array}{l}0.006 \\
(0.02)\end{array}$ & $\begin{array}{l}0.149 \\
(0.39)\end{array}$ & $\begin{array}{l}0.401 \\
(1.00)\end{array}$ & $\begin{array}{l}0.750 \\
(1.54)\end{array}$ & $\begin{array}{l}0.256 \\
(0.65)\end{array}$ & $\begin{array}{l}-0.130 \\
(0.35)\end{array}$ & $\begin{array}{l}0.113 \\
(0.29)\end{array}$ & $\begin{array}{l}0.285 \\
(0.74)\end{array}$ & $\begin{array}{l}0.227 \\
(0.50)\end{array}$ & $\begin{array}{l}0.175 \\
(0.42)\end{array}$ & $\begin{array}{l}0.233 \\
(0.64)\end{array}$ & $\begin{array}{l}0.174 \\
(0.45)\end{array}$ \\
\hline Time dummies & Yes & Yes & Yes & Yes & Yes & Yes & Yes & Yes & No & No & No & No & No & No \\
\hline Observations & 82 & 50 & 96 & 89 & 89 & 51 & 89 & 96 & 96 & 96 & 59 & 59 & 96 & 96 \\
\hline Number of Country Number & 14 & 13 & 14 & 15 & 15 & 14 & 15 & 14 & 14 & 14 & 13 & 13 & 14 & 14 \\
\hline
\end{tabular}


Table 6: Robustness tests for environmental quality indicators

Dependent variable: Average yearly satisfaction with democracy: 1 = not at all satisfied, $4=$ very satisfied

Random effects panel regressions

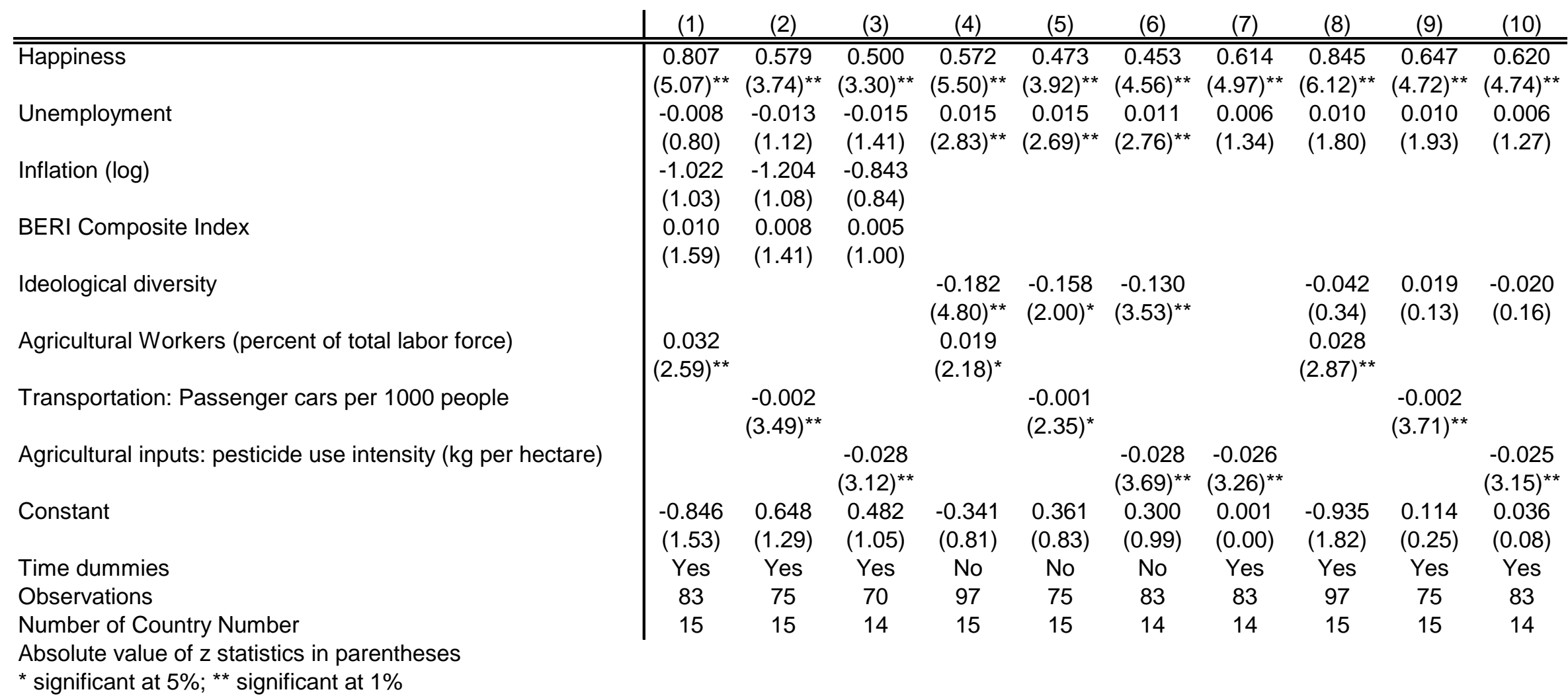

